\title{
RADIOCARBON DATING OF THE HISTORIC LIVINGSTONE TREE AT CHIRAMBA, MOZAMBIQUE
}

\author{
ADRIAN PATRUT ${ }^{a, b *}$, ROXANA T. PATRUT $^{c}$, MICHAEL J. SLATER $^{\mathrm{d}}$, \\ LASZLO RAKOSYc, DANIEL A. LÖWY', KARL F. VON REDEN ${ }^{f}$
}

\begin{abstract}
The article reports the AMS (accelerator mass spectrometry) radiocarbon dating results of the Livingstone Tree, a large African baobab on the right bank of the Zambezi, near Chiramba, Mozambique. In 1858, David Livingstone, who discovered the baobab, carved his monogram on the walls of its inner cavity. In 1996, the historic baobab was uprooted when a cyclone struck the area. Several wood fragments were extracted from the remains of the toppled tree. Five samples which originate from these fragments were subsequently dated by radiocarbon. The oldest sample had a radiocarbon date of $1598 \pm 17 \mathrm{BP}$, that corresponded in 1996 to a calibrated age of $1490 \pm 35$ calendar years. According to this value, the Livingstone Tree at Chiramba becomes one of the oldest known African baobabs, with an age of over 1500 years. The Livingstone Tree had a closed ring-shaped structure, that consisted of 4 fused stems around a false cavity and also 2 additional stems outside the ring.
\end{abstract}

Keywords: AMS radiocarbon dating, Adansonia digitata, tropical trees, age determination, closed ring-shaped structure, false cavity

a Babeş-Bolyai University, Faculty of Chemistry and Chemical Engineering, 11 Arany Janos, RO-400028, Cluj-Napoca, Romania.

b Babeş-Bolyai University, Raluca Ripan Institute for Research in Chemistry, 30 Fantanele, RO-400294 Cluj-Napoca, Romania.

c Babeş-Bolyai University, Faculty of Biology and Geology, 44 Republicii, RO-400015, ClujNapoca, Romania.

' Mozguide, 14 Kinross Road, Parkview, 2193 Johannesburg, South Africa.

e VALOR HUNGARIAE, Dept. of Science and Innovation, 4 Nagysándor József, 1054 Budapest, Hungary.

${ }^{f}$ NOSAMS Facility, Dept. of Geology \& Geophysics, Woods Hole Oceanographic Institution, Woods Hole, MA 02543, U.S.A.

*Corresponding author: apatrut@gmail.com 
ADRIAN PATRUT, ROXANA T. PATRUT, MICHAEL J. SLATER, LASZLO RAKOSY, DANIEL A. LÖWY, KARL F. VON REDEN

\section{INTRODUCTION}

The iconic African baobab (Adansonia digitata L.) is the best known and the most widespread of the eight or nine species of the Adansonia genus. The African baobab is endemic to the tropical arid savanna of the African continent. Its distribution throughout the tropics also covers several African islands and different areas outside Africa, where it has been introduced [1-5].

In 2005, our international team started an extended research project in order to clarify several controversial aspects related to the architecture, growth and age of the African baobab [6-16] and of other Adansonia species [17-20]. This research is based on a new approach, which is not limited to fallen specimens, but allows to investigate and date live individuals, as well. Our original approach consists of AMS (accelerator mass spectrometry) radiocarbon dating of minute wood samples extracted from inner cavities, deep entrances in the trunk, fractured stems and from the outer part (exterior) of large baobabs $[7,12,13]$.

According to research results, young baobabs, which usually start growing as single-stemmed trees, have the ability to produce new stems over time, developing structures of increasing complexity. Consequently, we focused on the investigation of superlative specimens, i.e., very large and potentially old baobabs. Our studies have identified a new type of architecture, which we named ring-shaped structure (RSS), that enables baobabs to reach large sizes and old ages. There are two subtypes of RSSs: the open RSS and the closed RSS. The most frequent is the closed RSS, in which the fused stems are disposed in a ring with a natural empty space inside, that we named false cavity. Certain specimens may also have additional stems outside the ring $[10,18]$. The first noticeable characteristic of false cavities, unlike normal ones, is the presence of bark on the cavity walls. The second characteristic is the fact that, due to stem growth, false cavities close progressively over time, retaining eventually only a small opening toward the exterior. The oldest African baobabs were found to have ages up to 2,500 years. By this value, the African baobab is the longest-living angiosperm in the world.

On September 16, 1858, the Scottish explorer and missionary David Livingstone discovered on the right bank of the Zambezi, near Chiramba, Mozambique, a very large baobab. The baobab was found to be 72 feet in circumference, at about three feet from the ground. Livingstone described it as "a magnificient baobab hollowed out into a good-sized hut". "It was hollow and had a wide high doorway to it. The space inside was 9 feet in diameter and about 25 feet high. A lot of bats clustered about the top of the roof and I noticed for the first time that this tree had bark inside as well as without" [21]. Livingstone carved his monogram on the bark of the inner cavity. In his honour, the baobab was named Livingstone Tree. It is also known as the baobab at Chiramba. 
In 1958, the explorer and film-maker Quentin Keynes, who was a grand-grandson of Darwin, decided to retrace the 1858-1864 Zambezi Expedition of Livingstone. On this occasion, Keynes rediscovered, with the assistance of locals, the Livingstone Baobab. He measured and filmed the wide baobab, which was "easily distinguished from others along the way by a narrow slit in its trunk. The slit provided a doorway taller than a man, and all three of us were able to walk upright through it into the tree's dark interior. Here we found a perfect natural shelter, which I estimated to be over 30 feet high and perhaps 30 feet around. Excitedly I peered around for initials... I turned to face the entrance way and there, a foot or so from the edge of the slit, was the mark that I immediately deciphered as the work of David Livingstone from the characteristically looped 'D' and 'L' of his signature" [22,23].

In 1965, C.L. Guy, a retired forester, measured the circumference of the baobab near Chiramba at the same three feet from the ground and found it to be 73.95 feet. By considering the growth rate over 107 years, Guy stated that the baobab could well be over 1,700 years old $[24,25]$.

In 1982, Wickens mentioned in his first monograph on baobabs, that "some trees, such as the famous Livingstone Tree at Chiramba on the lower Zambezi River, must be over 2000 years old" [1]. For over 30 years, based on Wickens' monograph, many books and articles about baobabs mentioned the tree at Chiramba as the oldest baobab. Despite the fame of this tree, the number of explorers and researchers who have seen it must be extremely low.

The mighty baobab was uprooted and died in January 1996, when Cyclone Bonita made landfall in Mozambique, causing severe damage. Moreover, most researchers are still unaware even now, after a quarter of a century, that the baobab near Chiramba has died.

In certain cases, the wood samples, which we investigated by radiocarbon, originated from the remains of baobabs and/or stems that had toppled months or even years prior to sampling. This was the case of Grotboom, our first dated African baobab [6], of Dorslandboom and Glencoe, two very old baobabs [8,9], as well as of Panke, the oldest known baobab [13]. Here we present the radiocarbon dating results of several wood samples collected from the remains of the collapsed Livingstone Tree at Chiramba, two years after its demise.

\section{RESULTS AND DISCUSSION}

The Livingstone Tree and its area. The baobab was located $3 \mathrm{~km} \mathrm{NW}$ of the Chiramba village, Chemba district, Sofala province, Mozambique. The local population belongs to the Makonde ethnic group. The GPS coordinates 
of the depression where the baobab once stood are $16^{\circ} 52.724^{\prime} \mathrm{S}, 034^{\circ} 37.531^{\prime}$ $\mathrm{E}$ and the elevation is $94 \mathrm{~m}$. The distance from this location to the Zambezi is $440 \mathrm{~m}$. The mean annual rainfall in the area is $715 \mathrm{~mm}$ and the mean annual temperature reaches $24^{\circ} \mathrm{C}$.

The baobab at Chiramba had a maximum height of $27 \mathrm{~m}$, the circumference at breast height (cbh; at $1.30 \mathrm{~m}$ above ground level) was 22.25 $\mathrm{m}$ and the overall wood volume (stems and branches) was around $350 \mathrm{~m}^{3}$ (Figure 1).

According to photographs and the video recording of Keynes, the baobab at Chiramba had a closed ring-shaped structure, with a ring composed of 4 perfectly fused stems around a false cavity. The baobab also had 2 additional stems outside the ring. The slit, which represented the entrance to the cavity, was around $6 \mathrm{~m}$ high. The false cavity, with the shape of a bell and with the walls covered by bark, had a height of $9 \mathrm{~m}$ and the quasi-circular base was $9 \mathrm{~m}$ around.

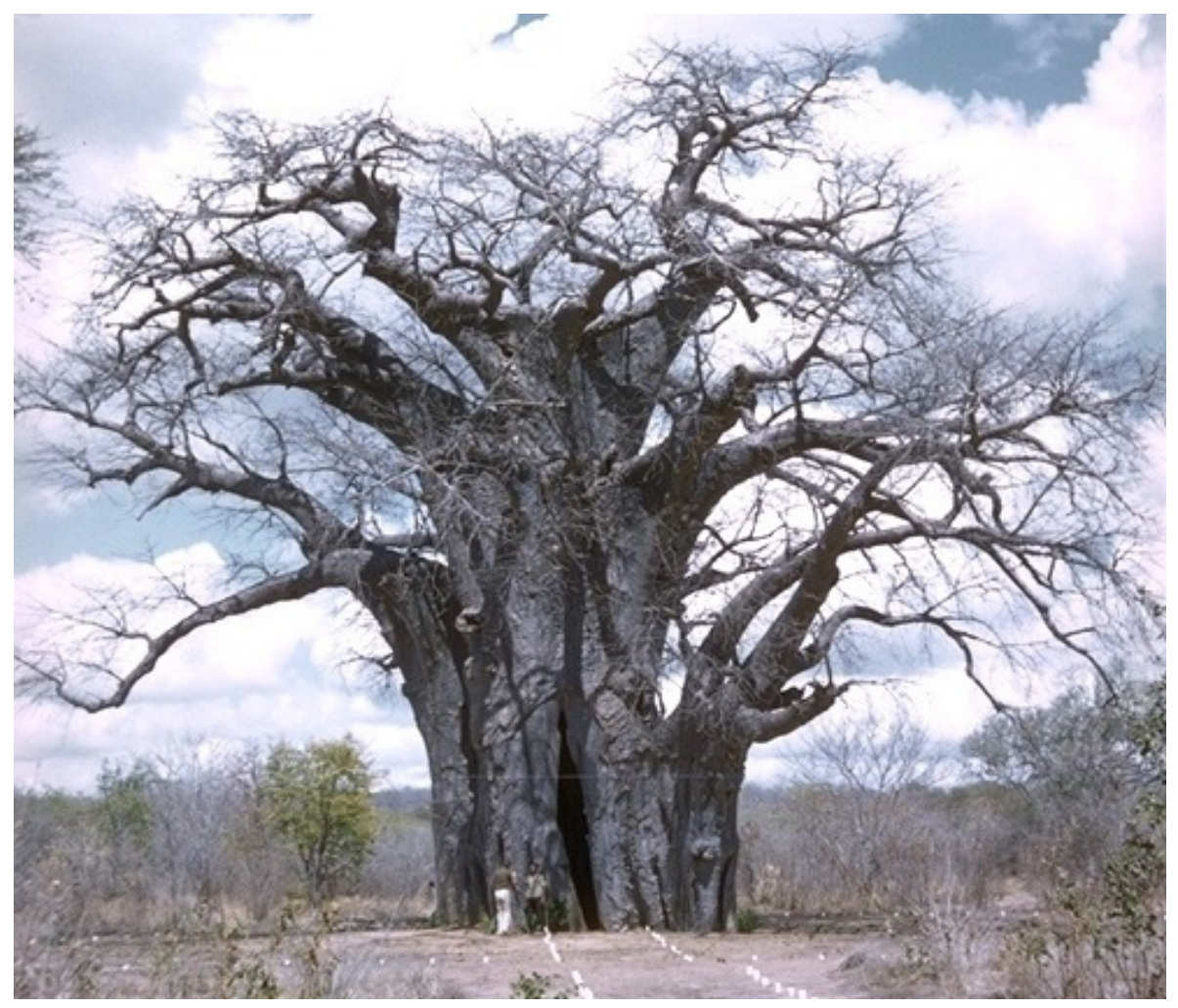

Figure 1. A very rare photo that shows the beautiful Livingstone Tree near Chiramba. One can observe the central slit, which is the entrance to the cavity. 
Wood samples. Several wood fragments, with the mass of several grams each, were collected as a souvenir from the partially decayed remains of the baobab. Five samples, which originate from these wood fragments, were labelled from $\mathrm{C}-1$ to $\mathrm{C}-5$.

AMS results and calibrated ages. Radiocarbon dates of the 5 samples are displayed in Table 1. The radiocarbon dates are expressed in ${ }^{14} \mathrm{C}$ yr $\mathrm{BP}$ (radiocarbon years before present, i.e., before the reference year 1950). Radiocarbon dates and errors were rounded to the nearest year.

Calibrated (cal) ages, expressed in calendar years CE (CE, i.e., common era), are also presented in Table 1 . The $1 \sigma$ probability distribution $(68.2 \%)$ was selected to derive calibrated age ranges. For two samples (C-3, $\mathrm{C}-4)$, the $1 \sigma$ distribution is consistent with one range of calendar years. For the other three samples (C-1, C-2, C-5), the $1 \sigma$ distribution is consistent with two ranges of calendar years. In these cases, the confidence interval of one range is considerably greater than that of the other; therefore, it was selected as the cal CE range of the sample for the purpose of this discussion. For obtaining single calendar age values of samples, we derived a mean calendar age of each sample from the selected range (marked in bold). Sample ages represent the difference between the year $1996 \mathrm{CE}$, when the baobab died, and the mean value of the selected range, which represents the assigned year, with the corresponding error. Sample ages and errors were rounded to the nearest $5 \mathrm{yr}$. We used the same approach for selecting calibrated age ranges and single values for sample ages in our previous articles on AMS radiocarbon dating of large and old angiosperms, especially baobabs [6-20,26,27].

Table 1. Radiocarbon dating results and calibrated ages of samples that originate from the Livingstone Tree at Chiramba.

\begin{tabular}{|c|c|c|c|c|}
\hline $\begin{array}{c}\text { Sample } \\
\text { code }\end{array}$ & $\begin{array}{l}\text { Radiocarbon } \\
\text { date [error] } \\
\left({ }^{14} \mathrm{C} \text { yr BP) }\right.\end{array}$ & $\begin{array}{l}\text { Cal CE range 1 } 1 \sigma \\
\text { [confidence } \\
\text { interval] }\end{array}$ & $\begin{array}{l}\text { Assigned year } \\
\text { [error] } \\
\text { (cal CE) }\end{array}$ & $\begin{array}{c}\text { Sample age }^{1} \\
\text { [error] } \\
\text { (cal CE) }\end{array}$ \\
\hline C-1 & $1210[ \pm 16]$ & $\begin{array}{l}860-898(41.5 \%) \\
930-960(26.7 \%)\end{array}$ & $\begin{array}{c}879 \\
{[ \pm 19]}\end{array}$ & $\begin{array}{c}1115 \\
{[ \pm 20]}\end{array}$ \\
\hline C-2 & $964[ \pm 18]$ & $\begin{array}{l}1046-1087(43.8 \%) \\
1132-1160(24.4 \%)\end{array}$ & $\begin{array}{l}1066 \\
{[ \pm 20]}\end{array}$ & $\begin{array}{c}930 \\
{[ \pm 20]}\end{array}$ \\
\hline C-3 & $1092[ \pm 25]$ & $990-1019(68.2 \%)$ & $\begin{array}{c}1005 \\
{[ \pm 15]}\end{array}$ & $\begin{array}{c}990 \\
{[ \pm 15]}\end{array}$ \\
\hline C-4 & $1598[ \pm 17]$ & $468-542(68.2 \%)$ & $\begin{array}{l}505 \\
{[ \pm 37]}\end{array}$ & $\begin{array}{l}1490 \\
{[ \pm 35]}\end{array}$ \\
\hline C-5 & $875[ \pm 26]$ & $\begin{array}{l}\mathbf{1 1 8 1 - 1 2 3 0}(\mathbf{6 2 . 1 \% )} \\
1252-1260(6.11 \%)\end{array}$ & $\begin{array}{l}1195 \\
{[ \pm 25]}\end{array}$ & $\begin{array}{c}800 \\
{[ \pm 25]}\end{array}$ \\
\hline
\end{tabular}

1 in 1996. 
Dating results of samples. Three samples (C-1, C-3, C-4) had radiocarbon dates over $1000 \mathrm{BP}$, namely $1210 \pm 16 \mathrm{BP}, 1092 \pm 25 \mathrm{BP}$ and $1598 \pm 17 \mathrm{BP}$. These values correspond to calibrated ages of $1115 \pm 20,990$ \pm 15 and $1490 \pm 35$ calendar yr. The other two samples (C-2, C-5) had lower radiocarbon dates, i.e., $964 \pm 18 \mathrm{BP}$ and $875 \pm 26 \mathrm{BP}$, that correspond to calibrated ages of $930 \pm 20$ and $800 \pm 25$ cal yr.

Age of the Livingstone Tree at Chiramba. Taking into account the particular circumstances in which the samples were collected, their initial position in the living baobab is not known. Therefore, we can only state that the baobab at Chiramba must have been older than the age of the oldest dated sample, i.e., most likely older than 1500 years.

\section{CONCLUSIONS}

The research discloses the AMS radiocarbon dating results of samples which originate from the remains of the famous Livingstone Tree, a large and old African baobab near Chiramba, Mozambique, that died in 1996.

Five wood samples were subsequently processed and dated by AMS radiocarbon. Three samples were found to have ages greater than $1000 \mathrm{BP}$. The oldest dated sample had a radiocarbon date of $1598 \pm 17 \mathrm{BP}$, that corresponded in 1996 to a calibrated age of $1490 \pm 35$ calendar years. According to dating results, one can state that the Livingstone tree at Chiramba was older than 1500 years. This value includes it among the oldest known African baobabs.

The baobab at Chiramba exhibited a closed ring-shaped structure, that consisted of 4 fused stems around a false cavity, and 2 additional stems outside the ring.

\section{EXPERIMENTAL SECTION}

Sample collection. Five small and partially decayed wood samples, which originate from the remains of the baobab, were processed and investigated by AMS radiocarbon dating.

Sample preparation. The standard acid-base-acid pretreatment method was used for removing soluble and mobile organic components [28]. The pretreated samples were combusted to $\mathrm{CO}_{2}$ by using the closed tube combustion method [29]. Next, $\mathrm{CO}_{2}$ was reduced to graphite on iron catalyst, under hydrogen atmosphere [30]. Finally, the resulting graphite samples were analyzed by AMS. 
AMS measurements. AMS radiocarbon measurements were performed at the NOSAMS Facility of the Woods Hole Oceanographic Institution (Woods Hole, MA, U.S.A.) by using the Pelletron ${ }^{\circledR}$ Tandem $500 \mathrm{kV}$ AMS system. The obtained fraction modern values, corrected for isotopic fractionation with the normalized $\delta^{13} \mathrm{C}$ value of $-25 \%$, were ultimately converted to a radiocarbon date.

Calibration. Radiocarbon dates were calibrated and converted into calendar ages with the OxCal v4.3 for Windows [31], by using the SHCal13 atmospheric data set [32].

\section{ACKNOWLEDGEMENTS}

Authors would like to acknowledge George Perry, who collected in 1998 wood fragments from the remains of the baobab. The research was funded by the Romanian Ministry of National Education CNCS-UEFISCDI under grants PN-II-ID-PCE-2013-76 and PN-III-P4-ID-PCE-2016-0776, Nr. 90/2017.

\section{REFERENCES}

1. G.E. Wickens, Kew Bull., 1982, 37(2), 172-209.

2. G.E. Wickens, P. Lowe, "The Baobabs: Pachycauls of Africa, Madagascar and Australia", Springer, Dordrecht, 2008, pp. 232-234, 256-257, 295-296.

3. D.A. Baum, Ann. Mo. Bot. Gard.,1995, 82, 440-471.

4. J.D. Pettigrew, L.K. Bell, A. Bhagwandin, E. Grinan, N. Jillani, J. Meyer, E. Wabuyele, C.E. Vickers, Taxon, 2013, 61, 1240-1250.

5. G.V. Cron, N. Karimi, K.L. Glennon, C.A. Udeh, E.T.F. Witkowski, S.M. Venter, A.E. Assobadjo, D.H. Mayne, D.A. Baum, Taxon, 2016, 65, 1037-1049.

6. A. Patrut, K.F. von Reden, D.A. Lowy, A.H. Alberts, J.W. Pohlman, R. Wittmann, D. Gerlach, L. Xu, C.S. Mitchell, Tree Physiol., 2007, 27, 1569-1574.

7. A. Patrut, K.F. von Reden, R. Van Pelt, D.H. Mayne, D.A. Lowy, D. Margineanu, Ann. Forest Sci., 2011, 68, 93-103.

8. A. Patrut, K.F. von Reden, D.A. Lowy, D.H. Mayne, K.E. Elder, M.L. Roberts, A.P. McNichol, Nucl. Instrum. Methods Phys. Res. Sect. B, 2010, 268, 910-913.

9. A. Patrut, K.F. von Reden, D.H. Mayne, D.A. Lowy, R.T. Patrut, Nucl. Instrum. Methods Phys. Res. Sect. B, 2013, 294, 622-626.

10. A. Patrut, S. Woodborne, K.F. von Reden, G. Hall, M. Hofmeyr, D.A. Lowy, R.T. Patrut, PLOS One, 2015, 10(1): e0117193. 
ADRIAN PATRUT, ROXANA T. PATRUT, MICHAEL J. SLATER, LASZLO RAKOSY, DANIEL A. LÖWY, KARL F. VON REDEN

11. A. Patrut, L. Rakosy, R.T. Patrut, I.A. Ratiu, E. Forizs, D.A. Lowy, D. Margineanu, K.F. von Reden, Studia UBB Chemia, 2016, LXI, 4, 7-20.

12. A. Patrut, S. Woodborne, K.F. von Reden, G. Hall, R.T. Patrut, L. Rakosy, J-M. Leong Pock Tsy, D.A. Lowy, D. Margineanu, Radiocarbon, 2017, 59(2), 435448.

13. A. Patrut, S. Woodborne, R.T. Patrut, L. Rakosy, D.A. Lowy, G. Hall, K.F. von Reden, Nat. Plants, 2018, 4(7), 423-426.

14. A. Patrut, R.T. Patrut, L. Rakosy, D.A. Lowy, D. Margineanu, K.F. von Reden, Studia UBB Chemia, 2019, LXIV, 2 (II), 411-419.

15. A. Patrut, S. Woodborne, R.T. Patrut, G. Hall, L. Rakosy, C. Winterbach, K.F. von Reden, Forests, 2019, 10, 983-993.

16. A. Patrut, A. Garg, S. Woodborne, R.T. Patrut, L. Rakosy, I.A. Ratiu, PLOS One, 2020, 15(1): e0227352.

17. A. Patrut, K.F. von Reden, P. Danthu, J-M. Leong Pock Tsy, R.T. Patrut, D.A. Lowy, PLOS One, 2015, 10(3): e0121170.

18. A. Patrut, K.F. von Reden, P. Danthu, J-M. Leong Pock-Tsy, L. Rakosy, R.T. Patrut, D.A. Lowy, D. Margineanu, Nucl. Instrum. Methods Phys. Res. Sect. B, 2015, 361, 591-598.

19. A. Patrut, R.T. Patrut, P. Danthu, J.-M. Leong Pock-Tsy, L. Rakosy, D.A. Lowy, K.F. von Reden, PLOS One, 2016, 11(1): e0146977.

20. R.T. Patrut, A. Patrut, J-M Leong Pock-Tsy, S. Woodborne, L. Rakosy, P. Danthu, I-A. Ratiu, J. Bodis, K.F. von Reden, Studia UBB Chemia, 2019, LXIV, 4, 131139.

21. C. Livingstone, D. Livingstone, "Narrative of an Expedition to the Zambezi and its Tributaries", 1865, Murray, London.

22. R. Cashel, "The Baobab in fact and fable", 1995, Cashel, Amanzimtoti, Natal.

23. Q. Keynes, "Dr. Livingstone, I presume! - A personal look at his Africa", 1960, documentary film.

24. C.L. Guy, Rhodesiana, 1967, 16, 17-26.

25. C.L. Guy, Proc. Trans. Rhodesian Sci. Assoc., 1970, 54(2), 68-84.

26. A. Patrut, R.T. Patrut, L. Rakosy, J. Bodis, D.A. Lowy, E. Forizs, K.F. von Reden, Studia UBB Chemia, 2016, LXI, 4, 21-30.

27. A. Patrut, S. Garnaud, O. Ka, R.T. Patrut, T. Diagne, D.A. Lowy, E. Forizs, J. Bodis, K.F. von Reden, Studia UBB Chemia, 2017, LXII, 1, 111-120.

28. I.U. Olsson, Radiometric Methods. In: B. Berglung, editor "Handbook of Holocene palaeoecolgy and palaeohydrology", Wiley, Chichester, 1986, pp. 273-312.

29. Z. Sofer, Anal. Chem., 1980, 52(8), 1389-1391.

30. J.S. Vogel, J.R. Southon, D.E. Nelson, T.A. Brown, Nucl. Instrum. Methods Phys. Res. Sect. B, 1984, 5, 289-293.

31. C. Bronk Ramsey, Radiocarbon, 2009, 51, 337-360.

32. A.G. Hogg, Q. Hua, P.G. Blackwell, M. Niu, C.E. Buck, T.P. Guilderson, T.J. Heaton, J.G. Palmer, P.J. Reimer, R.W. Reimer, C.S.M. Turney, R.H. Zimmerman, Radiocarbon, 2013, 55(4), 1889-1903. 